\title{
THE STRUCTURE AND STRATIGRAPHY OF THE ANORTHOSITE COMPLEX IN THE AREA NORTH OF BJØRNESUND, NEAR FISKENÆESSET
}

\author{
Brian J. Walton
}

Over the area extending about $15 \mathrm{~km}$ north of the inner part of Bjørnesund, near Fiskenæsset (fig. 16), numerous conformable layers of anorthositic rocks occur within gneisses. The rocks have been metamorphosed in the amphibolite and granulite facies, and affected by five episodes of folding. Only minor intrafolial and isoclinal folds have been recognised from the early phases $\left(F_{1}\right.$ and $\left.F_{2}\right)$ but major isoclinal folds which were initially recumbent with NE trending axes were produced by $F_{3}$ folds. These were subsequently refolded by $F_{4}$ and $F_{5}$ fold phases which produced major and minor tight to open upright folds with axial planes striking ESE and NE respectively. It is possible that the anorthosites have been affected by all five episodes of folding, but only $F_{3}$ to $F_{5}$ have been recognised in these rocks with certainty.

The stratigraphy of the anorthosite complex as described by Windley (1970, and this issue p. 41) has been used to interpret the structure in this area. It has proved extremely useful in recognizing the presence of the major $F_{3}$ isoclines. In contrast to the anorthositic rocks near Fiskenæsset, the anorthosites in the present area are locally heavily migmatized, and may only be preserved as lenses and blocks in the gneisses. Nevertheless, by mapping the different types of anorthositic rocks present as inclusions in the gneisses, it is often possible to establish a relict stratigraphy, without which it would have been extremely difficult to decipher the structure of the area.

Whereas, near Fiskenæsset the complex is generally folded into an isoclinal syncline, in this area it can be shown that the earliest major folds affecting the complex are $F_{3}$ anticlines and synclines. These folds are isoclinal and in some cases the complex in one limb of these folds has been totally reduced to inclusions of anorthositic and gabbroic rocks in the gneisses.

Fig. 16 shows a sketch map of the area and in the following the major structures as established with the help of the anorthosites are described. Fig. 17 gives a section through some of the major $F_{3}$ folds.

At the head of Bjørnesund (fig. 16, locality 1) the basal amphibolite (Windley's zone 1) occurs. The lower layered group with ultramafics and mafic gabbro (zo- 


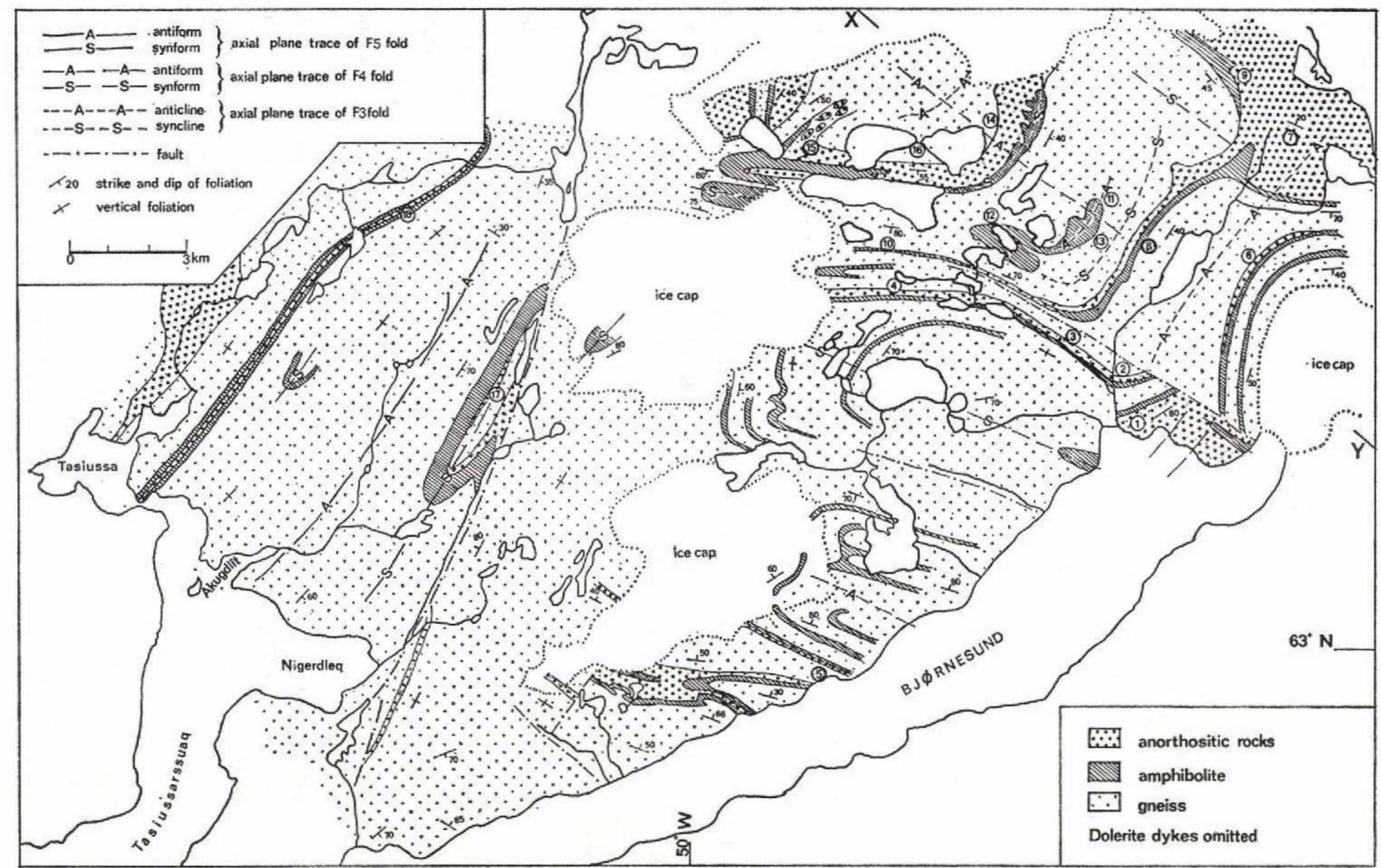

Fig. 16 Geological sketch map of the area north of Bjørnesund, Fiskenæsset region. 


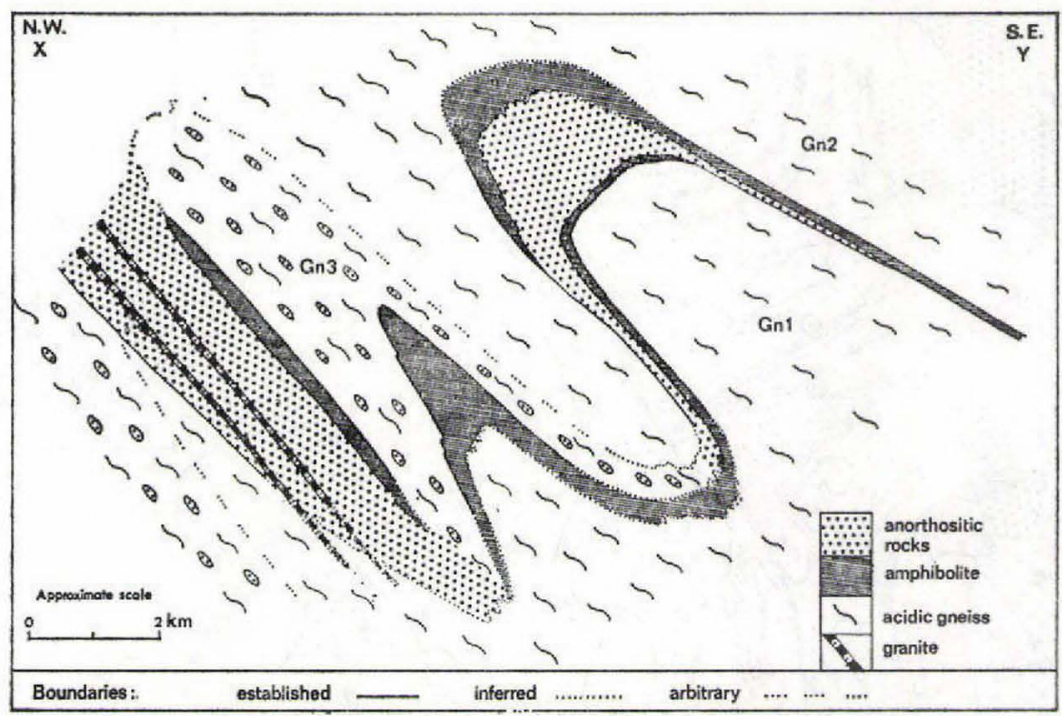

Fig. 17 Schematic section through the NE part of the area shown on the map of fig. 16. Gn 1, Gn 2 and Gn 3 indicate three groups of gneisses. See the text for further explanation.

nes 2-4) are only a few metres thick, but the homogeneous leucogabbro (zone 5) is well represented with large recrystallised plagioclase crystals deformed into a striking augen structure. The southern slopes of the mountain are made of anorthosite (zones 6-8), and the rocks here are affected by major $\mathrm{F}_{5}$ folds.

About $1 \mathrm{~km}$ north of Bjørnesund (locality 2) there is a narrow outcrop of anorthositic rocks. This youngs towards the south since peridotites with chromite layering (zone 2) occur at its northern margin (also at locality 3). Deformed homogeneous leucogabbro (unit 5) occurs further south within the outcrop, and amphibolite (zone 9) occurs on its southern margin. Further west, at locality 4, mafic gabbro shows relict igneous differentiated layering which youngs to the south. Several differentiated layers occur, each about $4 \mathrm{~m}$ thick, with hornblendite bases grading up into feldspathic tops. This anorthosite horizon follows round the major $\mathrm{F}_{4}$ fold and so comes down to the shore of Bjørnesund (locality 5). However, it is not possible to link the anorthosites of localities 1 and 2 by means of a fold, as both successions young to the south. A syn-metamorphic slide could be postulated between the two occurrences but no direct evidence was seen for this.

At locality 6 a thin anorthosite dips to the east and is overlain by amphibolite. This appears to be the upper limb of a major $F_{3}$ isoclinal anticline with its closure near locality 7 and its inverted lower limb at locality 8 (fig. 17). The anorthosite is more than $2 \mathrm{~km}$ thick in the fold closure and consists entirely of hornblendeand garnet-anorthosite (zones 6-8). It contains many patches of coarse-grained, relict igneous plagioclase including euhedral crystals up to $10 \mathrm{~cm}$ in diameter. 
A chromitite horizon (zone 7 ) occurs at locality 9 and is repeated by $F_{3}$ and $F_{4}$ folding. This clearly indicates the stratigraphic top of the complex so that the amphibolite immediately to the west must be zone 9 .

The anorthosite on the inverted lower limb of the major $F_{3}$ anticline thins out on the limb of the major $F_{4}$ antiform towards the SW. However, it can still be traced as blocks within the gneiss for several kilometres (locality 10). A little further north (locality 11) an amphibolite closure is surrounded by gneisses which contain relics of the anorthosite succession. Close to the amphibolite, on the lower western limb, occur abundant blocks of fine-grained leucogabbro, the most characteristic type of the lower layered group (zone 3). Further west extensive lenses of dark gabbro (zone 4) are found. These show excellent relict igneous differentiated layering. At locality 12 the layers are 1-2 m thick with hornblendehypersthene peridotite at the base grading up into feldspar-rich tops. These layers happen to be the right way up due to later $F_{4}$ folding, but along the strike to the NE another lens shows clearly inverted layering. Further west again blocks of coarse homogeneous leucogabbro (zone 5) and anorthosite (zones 6-8) produce excellent white agmatities. On the eastern, upper limb of this $F_{3}$ anticline only a few blocks of anorthosite occur in the gneiss (locality 13).

Further to the north-west (locality 14) occurs an excellent development of the anorthosite succession. The rocks dip mainly to the SE at about $40^{\circ}$. At the base the amphibolite and ultramafics (zones 1 and 2) are missing, but the lower layered group is well-developed and comprises about half the thickness of the sequence. Concordant pink, weakly-foliated, garnetiferous granite sheets occur. The dark gabbro and homogeneous leucogabbro zones are present and are overlain by anorthosite (zone 6) which thickens greatly to the north where it can be divided into a lower, relatively pure anorthosite sub-unit, and an upper hornblende gabbroic anorthosite. A chromitite and garnet anorthosite are locally present in contact with the marginal amphibolite. At the contact between the anorthosite and the upper marginal amphibolite, peridotite (zone 9) occurs continuously above an altitude of $1000 \mathrm{~m}$. A reaction zone, $5-10 \mathrm{~m}$ thick, is developed at the base of the peridotite with abundant sapphirine, ruby, ruby-spinel, pargasite and kornerupine, including kornerupine crystals up to $60 \mathrm{~cm}$ in length.

The marginal amphibolite thins out, or closes, to the north so that the anorthosite comes into contact with the overlying gneiss. However, this gneiss contains a well-preserved, relict, inverted, anorthosite succession. Therefore, the upper marginal amphibolite must be folded into an isoclinal $F_{3}$ syncline. The normal anorthosite succession is preserved in the crest of the major $F_{4}$ antiform in this part of the area. Further to the west-south-west the upper part of the anorthosite succession thins out, but the lower layered group passes into an agmatite composed of abundant large blocks of fine-grained leucogabbro in the gneiss (locality 15). In the gneiss below the complete normal anorthosite sequence, blocks of well-preserved, coarse, homogeneous leucogabbro (zone 5) occur at locality 16 . 
Also in the mountains immediately to the north, anorthositic streaks can be seen in the gneiss. It looks as though the gneiss here contains a relict, inverted, anorthosite sequence on the lower limb of another major $F_{3}$ anticline. The pink granite sheets in the layered group become more gneissic and less distinct towards the west-south-west in the limb of the major $\mathrm{F}_{4}$ antiform.

In the north-western part of the area, at locality 17 , a major $F_{5}$ syncline occurs with the following units of the succession well-developed: basal amphibolite (zone 1), dark gabbro (zone 4), homogeneous leucogabbro (zone 5). The anorthositic zones occur as rather fine-grained rocks banded with hornblende and plagioclase, and containing garnet in the upper parts. At locality 18 , the $100 \mathrm{~m}$ thick anorthositic unit contains dark gabbro (zone 4) near its northern margin, and garnet anorthosite (zone 8) on the southern margin, so that it youngs to the south. The amphibolites on each side must be zones 1 and 9 .

The acidic gneisses throughout the area are more or less banded, veined, hornblende-biotite gneisses, sometimes with hypersthene. On fig. 17 they have been subdivided into three groups: gneisses stratigraphically underlying the anorthosite complex Gn 1, gneisses stratigraphcally overlying the anorthosite complex $\mathrm{Gn} 2$, and gneisses within which large amounts of anorthositic inclusions are found $\mathrm{Gn}$ 3. Possibly this last group of gneisses was formed by injection of granite sheets into the anorthosite complex followed by continued deformation and metamorphism.

\section{Reference}

Windley, B. F. 1970: The stratigraphy of the Fiskenæsset Anorthosite Complex. Rapp. Grønlands geol. Unders. 35, 19-22. 